\title{
Foraging Behaviour of Damage-causing Birds in Table Grape Vineyards in the Orange River Valley, South Africa
}

\author{
E. Herrmann ${ }^{1 \mathrm{a}^{*}}$ and M.D. Anderson ${ }^{2}$
}

(1) Deciduous Fruit Producers' Trust Research, Suite 275, Postnet X5061, 7599 Stellenbosch, South Africa

(2) Department of Tourism, Environment \& Conservation, Private Bag X6102, 8300 Kimberley, South Africa

Date of submission for publication: April 2007

Date of acceptance for publication: September 2007

Key words: Bird damage, table grapes, foraging behaviour, feeding guild, Orange River

\begin{abstract}
The foraging behaviour of damage-causing birds in table grape vineyards was examined in the Orange River valley, Northern Cape Province, South Africa during the summer harvest season from November 2001 to January 2002. Based on a sample of $\mathbf{3 0 0}$ foraging acts observed, it was found that mixed-feeder species fed more on grapes during the first month of the harvest (November), when only about $13 \%$ of the vineyards bore ripe grapes, than during the subsequent two months (December and January). During the latter two months, insects were a more preferred food item, while grape foraging declined significantly despite the increased availability of grapes, suggesting a shift in their dietary preferences during the course of the harvesting season. A daily bimodal feeding pattern was also detected, with birds feeding more regularly on grapes and other food items from early to late morning and in the late afternoon, with a marked decrease during midday. There was also a preference for feeding from the top rather than from the side or bottom of bunches. There were clear differences in foraging strategies among the most commonly recorded species when these were not feeding on grapes. Mixed feeders fed on invertebrates by gleaning vine bark and foliage, hawking, or foraging in ground litter. Granivorous species generally foraged for plant matter, such as seeds, on the ground, but also foraged on grapes during the early stages of the harvest season (November).
\end{abstract}

\section{INTRODUCTION}

Bird damage to grape crops is of economic importance worldwide, resulting annually in large financial losses to producers (DeHaven \& Hothem, 1981; Hothem \& DeHaven, 1982; Jarvis \& Heÿl, 1990). Several extrinsic and intrinsic factors influence bird usage of vineyards and the level of damage inflicted by these birds (Watkins, 1999), while bird damage also varies spatially and temporally within and between single vineyards (Somers \& Morris, 2002). The factors that influence the extent of bird damage include the extrinsic characters, which refer to the structure and composition of the native or artificial habitat surrounding vineyards, and the intrinsic characters, which relate to the condition of the fruit, such as sugar content, colour and size (Watkins, 1999). While it is necessary to quantify the extent of damage to determine the necessity of a bird-control strategy (Otis, 1989; Mundy, 1988), an understanding of bird behaviour may also be crucial for defining a crop-damage problem. Identifying areas of vineyards that are susceptible to bird damage, for example, may be more useful than estimates of the total loss of crop yield (Somers \& Morris, 2002). Such knowledge will allow for deterrent efforts, amongst other methods, to be focused more effectively to reduce crop losses by birds. An understanding of foraging behaviour could thus be used to mitigate bird damage to grapes by taking cognisance of behavioural patterns when applying species- or situation-specific damage-mitigating strategies.
This paper aims to provide elementary knowledge on bird behaviour, particularly foraging behaviour, in table grape vineyards in the Orange River valley, Northern Cape Province, South Africa. On the basis of direct observations of the behaviour of free-ranging birds in table grape vineyards during a three-month harvest season, the following questions are addressed in this paper: (1) does the foraging frequency on grapes change during the course of the harvest season? (2) do birds exhibit a temporal feeding pattern in vineyards? (3) do birds feed at selected positions on grape bunches (e.g. top, side, or bottom)? and (4) what foraging strategies do birds employ in vineyards when not feeding on grapes? We also report on the species that are responsible for damage to grapes, and the implications that this may have on the implementation of damage-mitigating strategies.

\section{MATERIALS AND METHODS}

The study was conducted on table grape farms in the Kakamas

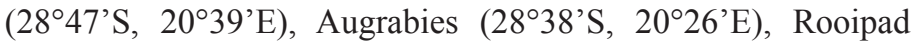
$\left(28^{\circ} 37^{\prime} \mathrm{S}, 20^{\circ} 20^{\prime} \mathrm{E}\right)$ and Blouputs $\left(28^{\circ} 28^{\prime} \mathrm{S}, 20^{\circ} 04^{\prime} \mathrm{E}\right)$ areas, situated between 70 to $100 \mathrm{~km}$ west-south-west of Upington in the Northern Cape Province, South Africa. The total extent of table grape vineyards cultivated on individual properties, as determined by a questionnaire survey of the farms in the study area, was approximately $50 \pm 38$ ha $( \pm \mathrm{SD})(\mathrm{n}=53)$. These extensive vineyards were generally composed of 'blocks' of individual cultivars, which numbered $17 \pm 14$ per property.

*Corresponding author: eherrmann@half.ncape.gov.za

Current address: Department of Tourism, Environment \& Conservation, Private Bag X6102, 8300 Kimberley, South Africa

Acknowledgements: We thank the grape producers and their managers in the study area who assisted in various ways. Some producers provided invaluable logistical support, in particular Izak Nel. For additional inputs into the project, we thank Haldo Compion, Drienus van Zyl, Richard Dean, Sue Milton, Christopher Somers, Ara Monadjem, Mike Jarvis, Julius Koen and the late Richard Liversidge. The project was funded by the Deciduous Fruit Producers' Trust. Some financial and logistical support was provided by the Northern Cape Department of Tourism, Environment and Conservation, for which we are very grateful. 
Observations of bird foraging behaviour were made concomitantly with bird damage assessments of vineyard blocks for 13, 17 and eight days in November, December and January respectively, from 2001-11-14 to 2002-01-11. A total of 18, 33 and 12 vineyard blocks of eight cultivars (Vitis spp.) were sampled during these respective months (Table 1), with a minimum of one and a maximum of three blocks sampled per day. Bird behaviour was recorded on foot along systematically sampled vineyard rows, which included (1) the first and last two rows of a block, (2) the outer edge of all other rows, and (3) every fifth row (small blocks) or tenth row (large blocks) of the 'internal' rows.

Observations were made from $06: 00$ to 18:00 on clear days with warm to hot weather $\left(25^{\circ} \mathrm{C}\right.$ to $\left.40^{\circ} \mathrm{C}\right)$, but not under adverse weather conditions (rain or strong wind). Foraging birds were identified and briefly observed using 9 × 25 binoculars. For each foraging act observed, of either a single bird or distinguishable group, the type of food item eaten (grape, insect or plant matter other than grape) was recorded, as well as the foraging strategy or manoeuvre employed (foraging for plant matter, such as seeds, or for insects on the ground, hawking insects in the air, gleaning insects from vines or from undergrowth weeds and ground litter). When birds were seen feeding on grapes, the position (top, side, or bottom) on which the bunch was being fed was noted. Only the first clearly distinguishable foraging act of each bird or group, when it was first observed, was recorded; hence all observations were independent. In cases where birds were flushed or startled by the observer, their behaviour was only recorded once the birds resumed behaviour that appeared to be unaffected by the presence of the observer. Potential bias due to the presence of the observer was considered negligible, as most species appeared to be well habituated to human activity in the vineyards. A total of 318 clearly distinguishable foraging acts were selected for analysis from a larger database of recorded behaviour. To test the effect of time of day on foraging frequency by the birds, data were separated into four equal periods of the day between 06:00 and 18:00 (06:00 to 09:00, 09:00 to $12: 00,12: 00$ to $15: 00$, and $15: 00$ to $18: 00$ ) when bird damage assessments were made. The chi-squared statistic was used to analyse the significance of differences in the fre-

\section{TABLE 1}

The number of vineyard blocks sampled per cultivar from 2001-11-14 to 2002-01-11 in the Orange River valley with respect to bird behaviour.

\begin{tabular}{lccc}
\hline Cultivar & \multicolumn{3}{c}{ Month } \\
\cline { 2 - 4 } & November & December & January \\
\hline Prime Seedless & 7 & 1 & 0 \\
Flame Seedless & 11 & 0 & 0 \\
Sugraone & 0 & 15 & 0 \\
Thompson's Seedless & 0 & 8 & 5 \\
La Rochelle & 0 & 5 & 2 \\
Red Globe & 0 & 1 & 5 \\
Regal Seedless & 0 & 2 & 0 \\
Victoria & 0 & 1 & 0 \\
\hline Total & $\mathbf{1 8}$ & $\mathbf{3 3}$ & $\mathbf{1 2}$ \\
\hline
\end{tabular}

quency distributions of food items eaten (contingency tables) and the types of foraging manoeuvres (contingency tables and test for homogeneity) between the predominant grape-harvesting months (November, December and January).

\section{RESULTS}

Eleven bird species of primarily three feeding guilds were recorded feeding on grapes, namely mixed feeders (fruit and insects or seeds and insects), granivores (seeds), and frugivores (fruit) (Table 2). Nearly half of these were resident mixed feeders (five species), while the others were resident granivores (three species), resident frugivores (two species), and nomadic granivores (one species).

Sample sizes of foraging acts at the species level were too small to allow analysis for all but two species (African red-eyed bulbul and Orange River white-eye). The frequency distributions of food items eaten (grapes versus insects) between the three months was significantly different for African red-eyed bulbul $\left(\chi^{2}=19.054\right.$, $\mathrm{df}=2, \mathrm{p} \leq 0.01)$ and Orange River white-eyes $\left(\chi^{2}=18.695\right.$, $\mathrm{df}=2, \mathrm{p} \leq 0.01$ ) (Table 3 ) and for all mixed-feeders combined $\left(\chi^{2}=58.681, \mathrm{df}=2, \mathrm{p} \leq 0.01\right)$, with these species feeding more frequently on grapes during November than both December or January. During the latter two months, mixed feeders foraged more frequently on insects than grapes. This foraging pattern was evident despite the low availability of grapes during November, the first month of the harvest season, when only $13 \%$ of the vineyards bore ripe grapes. Grape availability increased markedly thereafter, with 44 and $43 \%$ of the vineyards bearing ripe grapes during December and January respectively (Orange River Producers' Alliance, unpublished data). For granivores and frugivores, sample sizes were too small, even with all respective species combined, to test for a significance difference in the frequency of food items eaten between the three months.

When the three months of the harvest season are combined, the frequency with which birds fed on grapes differed significantly with time of day. Birds fed more frequently during the late morning (09:00-12:00, 43\% of observations, $\mathrm{n}=84)$ and early morning (06:00-09:00, 37\%), followed by the late afternoon (15:00-18:00, $14 \%)$ and mid afternoon (12:00-15:00, 6\%) $\left(\chi^{2}=31.523\right.$,

\section{TABLE 2}

The status and feeding guild of 11 bird species recorded feeding on table grapes during the study period (November 2001 to January 2002).

\begin{tabular}{lcc}
\hline Bird species & Status & Diet \\
\hline White-backed mousebird Colius colius & Resident & Frugivore \\
Red-faced mousebird Urocolius indicus & Resident & Frugivore \\
African red-eyed bulbul Pycnonotus nigricans & Resident & Mixed feeder \\
Karoo thrush Turdus smithi & Resident & Mixed feeder \\
Orange River white-eye Zosterops pallidus & Resident & Mixed feeder \\
Cape sparrow Passer melanurus & Resident & Mixed feeder \\
Southern masked weaver Ploceus velatus & Resident & Mixed feeder \\
Red-billed quelea Quelea quelea & Nomad & Granivore \\
Southern red bishop Euplectes orix & Resident & Granivore \\
Yellow canary Crithagra flaviventris & Resident & Granivore \\
White-throated canary Crithagra albogularis & Resident & Granivore \\
\hline
\end{tabular}




\section{TABLE 3}

Frequencies with which certain food items were eaten by damage-causing birds across the three predominant grape-harvesting months (values are percentages). An asterisk (*) marks those species for which sample sizes were large enough for the statistical analyses at the species level, with all sample sizes indicated by (n).

\begin{tabular}{|c|c|c|c|c|c|c|c|c|c|c|c|c|}
\hline \multirow{2}{*}{ Bird species } & \multicolumn{4}{|c|}{ November } & \multicolumn{4}{|c|}{ December } & \multicolumn{4}{|c|}{ January } \\
\hline & Grape & Insect & Seed & (n) & Grape & Insect & Seed & (n) & Grape & Insect & Seed & (n) \\
\hline White-backed mousebird & 100 & 0 & 0 & (2) & 100 & 0 & 0 & (3) & 0 & 0 & 0 & $(0)$ \\
\hline Red-faced mousebird & 100 & 0 & 0 & (6) & 100 & 0 & 0 & (3) & 100 & 0 & 0 & $(2)$ \\
\hline African red-eyed bulbul* & 63 & 37 & 0 & $(38)$ & 23 & 77 & 0 & $(48)$ & 16 & 84 & 0 & (19) \\
\hline Karoo thrush & 38 & 62 & 0 & (13) & 5 & 95 & 0 & $(22)$ & 0 & 100 & 0 & $(10)$ \\
\hline Orange River white-eye* & 66 & 34 & 0 & (29) & 16 & 84 & 0 & (19) & 0 & 100 & 0 & (9) \\
\hline Cape sparrow & 61 & 9 & 30 & (23) & 10 & 24 & 67 & $(21)$ & 0 & 0 & 100 & (1) \\
\hline Southern masked weaver & 0 & 0 & 100 & (1) & 67 & 0 & 33 & (3) & 0 & 0 & 0 & $(0)$ \\
\hline Red-billed quelea & 50 & 0 & 50 & (2) & 0 & 0 & 0 & $(0)$ & 0 & 0 & 0 & $(0)$ \\
\hline Southern red bishop & 33 & 0 & 67 & (9) & 9 & 0 & 91 & (11) & 0 & 0 & 100 & (3) \\
\hline Yellow canary & 100 & 0 & 0 & (1) & 20 & 0 & 80 & (5) & 0 & 0 & 100 & (1) \\
\hline White-throated canary & 100 & 0 & 0 & (2) & 14 & 0 & 86 & (7) & 50 & 0 & 50 & (2) \\
\hline
\end{tabular}

$\mathrm{df}=3, \mathrm{p} \leq 0.01)$. The frequencies of foraging for food items such as grapes, insects and seeds were independent of one another with respect to time of day $\left(\chi^{2}=9.78, \mathrm{df}=6\right.$, n.s. $)$, with a lowered foraging frequency during mid-afternoon (Figure 1).

For all species combined, birds were seen feeding more frequently on grapes from the top of bunches ( $50 \%$ of observations, $\mathrm{n}=58)$ than either from the side $(28 \%)$ or bottom (22\%) during November $\left(\chi^{2}=7.483, \mathrm{df}=2, \mathrm{p} \leq 0.05\right)$, and similarly during December $(61 \%, 33 \%$ and $6 \%$ respectively; $\mathrm{n}=18)\left(\chi^{2}=8.333, \mathrm{df}=2\right.$, $\mathrm{p} \leq 0.05)$. January was not included in the analysis because of the small sample size of grape feeding observations for that month. There was no significant difference in the foraging position between November and December $\left(\chi^{2}=2.598, \mathrm{df}=2\right.$, n.s. $)$, suggesting that birds continually preferred to feed on the top rather than from the side or bottom of bunches.

For the most common species, there were broad differences in foraging behaviour that were not related to grape feeding, such as hawking, gleaning or foraging for insects on the ground. Orange River white-eyes gleaned insects from vine stems and leaves more frequently $(67 \%$ of observations, $n=42)$ than either foraging on the ground $(24 \%)$ or hawking $(10 \%)\left(\chi^{2}=22.286, \mathrm{df}=2\right.$, $\mathrm{p} \leq 0.01)$, while African red-eyed bulbuls hawked insects in the air more frequently $(58 \%$ of observations, $\mathrm{n}=86)$ than foraging on the ground $(41 \%)$ or gleaning $(1 \%)\left(\chi^{2}=43.977, \mathrm{df}=2\right.$, $\mathrm{p} \leq 0.01)$. Other species that foraged exclusively on the ground include other mixed-feeders such as Karoo thrush and Cape sparrow, and granivores such as southern red bishop, white-throated canary and yellow canary.

\section{DISCUSSION}

The results of this study show that there were significant changes in the foraging behaviour of damage-causing birds in vineyards during the grape-harvesting season. The most marked of these was the decrease in feeding frequency on grapes by mixed feeders and granivores as the harvest season progressed, followed by an increase in foraging for insects and plant matter such as seeds. The significant differences with which food items were selected over the study period suggest a temporal change in the availability of food or in the nutritional requirements of the birds, or both. The most intense grape-feeding period (November) coincided with the availability of the earliest ripening, but least extensively cultivated cultivars (Prime and Flame Seedless). Hence, the availability of grapes during November, compared to December and January, was very low, with only $13 \%$ of the region's vineyards bearing ripe grapes. This suggests that grapes are an attractive and desirable food source early in the harvest season, irrespective of their quantitative availability. Bird preference for early-ripening crops has been recorded in fruits other than grapes, including cherries (Virgo, 1971; Tobin et al., 1991), field corn (Bridgeland \& Caslick, 1983) and apples (Mitterling, 1965; Tobin et al., 1989).

The ripening of these first cultivars follows the post-winter period, when natural food resources possibly are limited mostly to arid-zone avifaunal species (Dean, 1995), and thus could serve as a valuable food source to improve their nutritional status. The sugar content in fruit, for example, has been identified as an important cue for foraging birds (White \& Stiles, 1985) with birds being able to distinguish between different sugar levels (Levey, 1987), while Watkins (1999) found that bird damage to grapes increased significantly once fruit sugar concentrations exceeded a certain threshold. There is, however, still uncertainty as to which cues attract birds to ripening grapes, and why (Saxton et al., 2004). Besides sugar, numerous other chemical and physical properties, which change simultaneously as the fruit develops, may influence fruit choice by birds (Watkins, 1999).

The increased foraging for insects by mixed feeders from December could be related to reproductive activity, as many aridzone species commence with breeding at this time (Keith et al., 1992; Maclean, 1993; Harrison et al., 1997). Because of their high protein content, insects are a crucial dietary item for offspring during their early stages of development to ensure growth and survival (Maclean, 1990), and hence would be a much soughtafter food item for provisioning birds. Several species of mixed feeders, granivores and insectivores were found nesting and rearing offspring in the vineyards during the peak insect-foraging months of December and January, but not in November. 


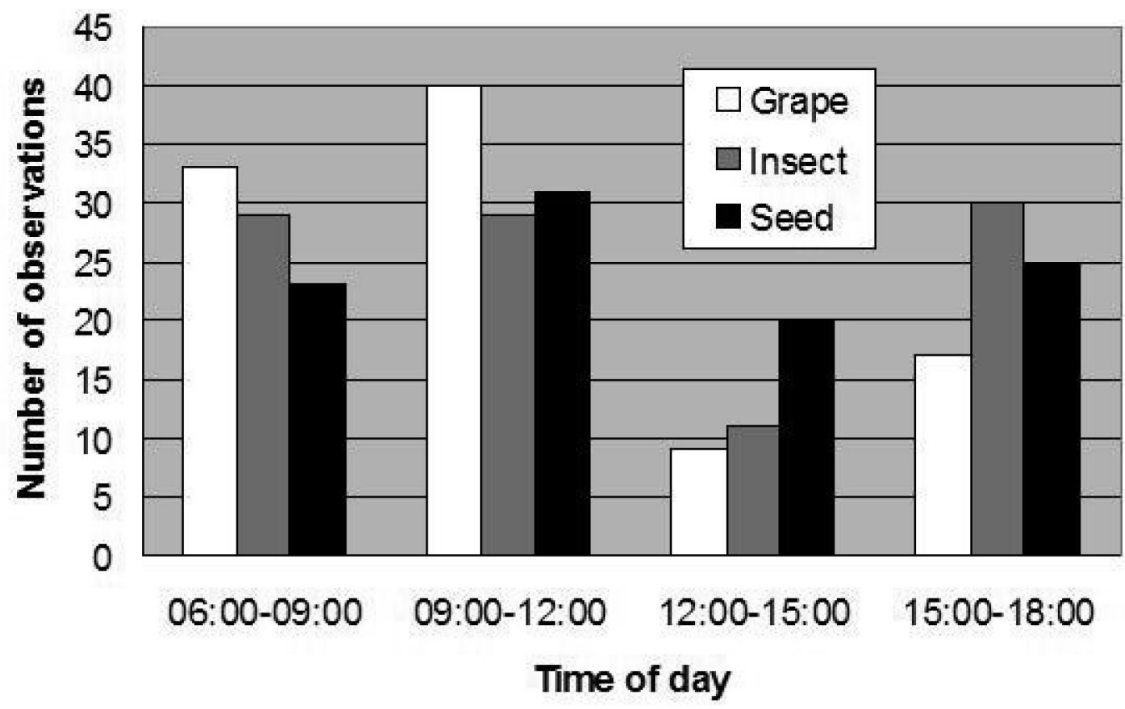

FIGURE 1

Number of observations of birds feeding on grapes and other food items at different times of the day throughout the harvest season.

Throughout the harvest season, birds foraged more frequently on grapes and other food items during early to late morning and in the late afternoon, with a decline during mid-afternoon. This bimodal foraging pattern is documented well for many other bird species (Palmgren, 1949; Yim\& Kang, 1982; Zajac, 1983; Bryant et al., 1984; Watkins, 1999) and is the result of birds replenishing depleted body reserves in the morning, and building reserves in the late afternoon in preparation for the night (Hintz \& Dyer, 1970). This midday period of lowered activity should thus result in lowered damages to grape crops at this time of day. Hence, efforts to mitigate damage should therefore be employed at those times when vineyards are most vulnerable to bird damage, i.e. early to late morning and in the late afternoon.

Birds showed a preference for feeding from the top of grape bunches, followed by the side and then the bottom. The strategy of perching on top of a bunch while feeding is most probably to reduce energy expenditure (Moermond, 1990). Birds make costbenefit decisions when deciding on a feeding strategy, preferring to sit either next to or reaching up to fruit rather than hang upside down to ingest the food (Moermond, 1990). Cape sparrows, for example, are reported to cause damage mostly to the upper parts of bunches in the Western Cape, South Africa (Myburgh \& Jarvis, 1986). The use of non-perforated bags for protecting individual bunches can be considered effective in reducing damage, as these provide adequate protection for both the top and sides of the bunch, which are most vulnerable to attack from the majority of foraging bird species. A specie mainly responsible for damaging the underside of bunches in vineyards surveyed in the current study was the Karoo thrush. This primarily ground-dwelling species (Hockey et al., 2005) was recorded taking whole grapes from the underside of bunches by darting upwards from the ground, plucking one grape at a time (E.H. pers. obs.). A similar strategy was recorded for related blackbirds (Turdus merula) in vineyards in the Marlborough District, New Zealand (Saxton et al., 2004). This is probably a more cost-effective foraging method than hanging or balancing on bunches and this species' foraging options hence may be limited by its large size relative to other damage-causing species.
The foraging strategies employed by birds when feeding on insects and seeds were typical for the respective species. Among the mixed feeders, white-eyes generally gleaned vine bark and foliage, while bulbuls and thrushes were hawkers and ground foragers respectively (Maclean, 1993). The extent to which invertebrate populations are controlled by these mixed-feeder species in vineyards may be important, and possibly of benefit to the table grape industry. Silvereyes (Zosterops sp.) in Australia are considered to have some beneficial effects in insect control (Rooke, 1984). This usefulness of some confirmed damage-causing bird species is also reported by Weatherhead (1982), Jarvis (1990) and Kirk et al. (1996) .

Most granivores, such as bishops and canaries, forage for seed on the ground (Maclean, 1993) and, although they were also reported to feed on grapes during November, there was a tendency for most species to forage for seed more frequently in the following months (Table 3). However, where large mixed flocks of different species occur, birds may gain food-selection information by watching each other (Moriarty, 1985). Hence, granivorous species may learn to feed on grapes by watching others, particularly during the first month of the harvest, when grape feeding was most intense. Seeding grasses and weeds in inter-row spaces may enhance the attractiveness of a block to birds (Sinclair \& Porter, 1994), and particularly to granivores. Such conditions may initially attract large flocks of granivores, which, after establishing a feeding pattern there, may turn to grapes and exacerbate the damage.

Ten of the eleven species recorded feeding on grapes in this study were sedentary, with only one species being somewhat nomadic in its movements (Table 2). Hence, the majority of species can be expected to be present throughout the year. Furthermore, these species tend to move about in pairs or small loose flocks of less than five individuals (Myburgh \& Jarvis, 1986; Maclean, 1993), rather than in large, mobile flocks as reported elsewhere for some damagecausing species (Myburgh \& Jarvis, 1986; Fisher, 1992). Damagemitigating methods that rely on either visual or auditory stimuli to deter birds from vineyards may therefore be less effective, as they may be less practical for deterring small flocks or groups of birds of various species that are spread across a vineyard than for deterring a limited number of large flocks of a single species. Large single- 
species flocks can be deterred successfully with a combination of visual and auditory stimuli in some situations, but this requires a concerted and sustained effort (Fisher, 1992).

\section{CONCLUSIONS}

Knowledge about the behaviour of birds in vineyards may be an important element for developing effective damage-mitigating strategies so that these can be implemented purposefully and correctly. Although the results presented here do not cover the wide array of behavioural characteristics that may be related to the extrinsic and intrinsic factors that affect damage caused by birds, they do support the general trends observed in other studies.

Damage caused by birds is most intense early in the harvest season, with a distinguishable daily bimodal foraging pattern. Efforts to mitigate damage should therefore be employed at those times when vineyards are most vulnerable to bird damage, i.e. early in the harvest season and especially in early-ripening cultivars. Deterring devices that rely on either visual or auditory stimuli should only be operative during mornings and late afternoons, when the birds are most active and inclined to forage on grapes. Prolonged exposure to control devices results in birds becoming habituated to the devices. Where vineyard damage is severe or where birds are not easily deterred, protection of individual bunches using non-perforated bags could be considered, as these provide adequate protection for both the top and sides of the bunch, which are most vulnerable to attack from foraging birds.

However, prior to selecting and implementing site-specific damage-mitigation measures, an effort should be made to identify genuine damage-causing bird species, as this will determine what approach should be taken in the damage-mitigating programme. Additional information should be gathered on factors that may affect bird behaviour and damage caused by birds, such as identifying well-used flight paths by birds into vineyards, the physical location and type of cultivar of the vineyard block relative to neighbouring blocks, and the distance from favourable bird habitats. By so doing, it should be possible to identify areas of the property and blocks that are most susceptible to bird damage, which means that damage-mitigating measures can be focused appropriately. Note, however, that the behavioural pattern of damage-causing birds may vary greatly between vineyards and even between blocks of the same cultivar. Hence, management measures may not be effective for all situations involving bird damage.

\section{LITERATURE CITED}

Bridgeland, W.T. \& Caslick, J.W., 1983. Relationships between cornfield characteristics and blackbird damage. J. Wildl. Manage. 47, 824-829.

Bryant, H., Hone, J. \& Nicholls, P., 1984. The acceptance of dyed grain by feral pigs and birds 1. Birds. Aust. Wildl. Res. 11, 509-516.

Dean, W.R.J., 1995. Where birds are rare or fill the air: the protection of the endemic and the nomadic avifaunas of the Karoo. Thesis, University of Cape Town, Private Bag, 7701 Rondebosch, South Africa.

DeHaven, R.W. \& Hothem, R.L., 1981. Estimating bird damage from damage incidence in wine grape vineyards. Am. J. Enol. Vitic. 32, 1-4.

Fisher, A., 1992. Vigilance and variation: the key to victory in the vineyards. Wine Ind. J. 7, 140-143.

Harrison, J.A., Allan, D.G., Underhill, L.G., Herremans, M., Tree, A.J., Parker, V. \& Brown C.J. (eds), 1997. The atlas of southern African birds, vol 2. BirdLife South Africa, Johannesburg.

Hintz, J.V. \& Dyer, M.I., 1970. Daily rhythm and seasonal change in the summer diet of adult red-winged blackbirds. J. Wildl. Manage. 34, 789-799.
Hockey, P.A.R., Dean, W.R.J. \& Ryan, P.G. (eds), 2005 (7 $7^{\text {th }}$ ed). Roberts' birds of Southern Africa. John Voelcker Bird Book Fund, Cape Town.

Hothem, R.L. \& DeHaven, R.W., 1982. Raptor-mimicking kites for reducing bird damage to wine grapes. In: Marsh. R.E. (ed). Proc. $10^{\text {th }}$ Verte. Pest Conf., February 1982, Monterey, California. pp. $171-178$.

Jarvis, M.J.F., 1990. Reducing bird damage in vineyards. Deciduous Fruit Grower 40, 12-13.

Jarvis, M.J.F \& Heÿl, C.W., 1990. Reducing bird damage in vineyards. Deciduous Fruit Grower 41, 365-367.

Keith, S., Urban, E.K. \& Fry, C.H., 1992. The Birds of Africa, vol 4. Academic Press, London.

Kirk, D.A., Evenden, M.D. \& Mineau, P., 1996. Past and current attempts to evaluate the role of birds as predators of insect pests in temperate agriculture. Curr. Ornith. 13, 175-269.

Levey, D.J., 1987. Sugar-tasting ability and fruit selection in tropical fruit-eating birds. The Auk 104, 173-179.

Maclean, G.L., 1990. Ornithology for Africa. University of Natal Press, Pietermaritzburg.

Maclean, G.L., 1993. Roberts' birds of southern Africa. John Voelcker Bird Book Fund, Cape Town.

Mitterling, L.A., 1965. Bird damage on apples. Proc. Am. Soc. Hortic. Sci. 87, 66-72.

Moermond, T.C., 1990. A functional approach to foraging: morphological, behaviour and the capacity to exploit, In: Morrison, M.L., Ralph, C.J., Verner, J. \& Jehl, J.R. Jr. (eds). Avian foraging: theory, methodology, and applications. Studies in Avian Biology, no 13. Cooper Ornithological Society, San Diego. pp. $427-430$.

Moriarty, D.J., 1985. The adaptive nature of bird flocks. The Biologist 58, 67-79.

Mundy, P.J., 1988. The problem of birds as pests in Zimbabwe. In: Bennun, L. (ed). Proc. 7th Pan-Afr. Ornith. Congr., August/September 1988, Nairobi, Kenya. pp. $271-275$.

Myburgh, A.C. \& Jarvis, M.J.K., 1986. Fruit-eating birds. In: Myburgh, A.C. (ed). Crop pests in southern Africa, vol 1. Plant Protection Research Institute, Department of Agriculture and Water Supply, Pretoria. pp. $77-80$.

Otis, D.L., 1989. Damage assessments: estimation methods and sampling design. In: Bruggers, R.L. \& Elliott, C.C.H. (eds). Quelea quelea. Africa's bird pest. Oxford University Press, Oxford. pp. $79-101$.

Palmgren, P., 1949. On the diurnal rhythm of activity and rest in birds. Ibis 91, 561-576.

Rooke, I., 1984. The secretive silvereyes. J. Agric. - Western Aust. 25, 19-21.

Saxton, V.P., Creasy, G.L., Paterson, A.M. \& Trought, M.C.T., 2004. Experimental method to investigate and monitor bird behaviour and damage in vineyards. Am. J. Enol. Vitic. 55(3), 288-291.

Sinclair, R. \& Porter, R.E.R., 1994. Pests - Birds. In: Nicholas, P., Magarey, P. \& Wachtel, M. (eds). Diseases and pests, vol 1. Winetitles. Cowandilla, Australia. pp. $57-61$.

Somers, C.M. \& Morris, R.D., 2002. Birds and wine grapes: foraging activity causes small-scale damage patterns in single vineyards. J. Appl. Ecol. 39, 511-523.

Tobin, M.E., Dolbeer, R.A., Webster, C.M. \& Seamans, T.W., 1991. Cultivar differences in bird damage to cherries. Wildl. Soc. Bull. 19, 190-194.

Tobin, M.E., Dolbeer, R.A. \& Woronecki, P.P., 1989. Bird damage to apples in the mid-Hudson Valley at New York. Hortic. Sci. 24, 859

Virgo, B.B., 1971. Bird damage to sweet cherries on the Niagara Peninsula, Ontario. Can. J. Plant Sci. 51, 415-423.

Watkins, N.G., 1999. Ecological correlates of bird damage in a Canterbury vineyard. Thesis, Lincoln University, PO Box 84, 7647 Canterbury, New Zealand.

Weatherhead, P.J., 1982. Assessment, understanding and management of blackbird-agriculture interactions in eastern Canada. In: Marsh, R.E. (ed). Proc. $10^{\text {th }}$ Verte. Pest Conf., February 1982, Monterey, California. pp. 193 - 196.

White, D.W. \& Stiles, E.W., 1985. The use of refractometry to estimate nutrient rewards in vertebrate dispersed fruits. Ecology 66, 303-307.

Yim, Y.J. \& Kang, S.J., 1982. Control of bird damage in the vineyard. Hortic. Abstr. 54, 868.

Zajac, R., 1983. Biosonic and piroacoustics as a protection means of large cherry orchards against starlings in Poland. Fruit Sci. Rep. 10, 113-133. 